\title{
The Effectiveness of International Law in Resolving International Armed Conflicts
}

\author{
Dr. Derar Fares Masoud
}

\begin{abstract}
The purpose of this research is to identify the role and effectiveness of international law in resolving armed conflicts between States, as well as the negative effects of the emergence of armed conflicts between States, and the role of the United Nations in resolving armed conflicts and consolidating international peace. On the descriptive and historical approaches. The research concluded that international law was aimed at regulating relations between states and reducing armed conflicts between them through texts and principles restricting the right of parties to use methods and methods of warfare. Through peacemaking, peacekeeping, and humanitarian assistance.
\end{abstract}

Keywords: International Law - International Armed Conflicts - United Nations

DOI: $10.7176 / \mathrm{JLPG} / 91-15$

Publication date: November $30^{\text {th }} 2019$

\section{Introduction}

The phenomenon of human armed conflict was inherent from the outset, and man used it for the basic purpose of maintaining survival to improve his living conditions. The form of armed conflict, especially military force, has evolved into an indirect use of force in the form of threats or pressures of all kinds, usually called means of coercion. International and regional organizations have emerged in this era, which have taken on the task of drafting laws governing armed conflicts and seeking to reduce and mitigate them. Of their effects.

The international community has also made great efforts to regulate and define the prevention of the use of force. The United Nations, in order to achieve international peace and security and to prohibit the use of force in international relations and to settle armed conflicts, has drafted an international law on relations between States that prohibits resorting to war except in self-defense. And the peaceful settlement of disputes, and the imposition of sanctions and penalties for violators.

\section{Research problem}

Relations between human beings have evolved since the beginning of the creation, and bifurcated and expanded, including societies and states, and these relations ranging from conflict, peace, agreement and war at the international level, in various political, intellectual, social, military and even geographic aspects, which became necessary with the presence of a legal officer to protect the agreement and determine Dimensions and crystallization of the conflict and seeks to end by all means and means available, in order to reduce the devastating effects of any conflict of any kind; which led to the emergence of international law, which came with principles and principles agreed upon internationally, governing relations between States.

From the above, the problem of the study emerges in answering the following key question: What is the role and effectiveness of international law in the resolution of armed conflicts between States?

\section{The aim of the research}

This paper seeks to identify the role and effectiveness of international law in resolving armed conflicts between States through the following:

a. Recognize the concept of international law and its role in conflict resolution.

b. Track the origins and stages of development of international relations.

c. Identify the negative effects of the emergence of armed conflicts between States, and the role of the United Nations in resolving armed conflicts and consolidating international peace.

d. Identify the means used by the United Nations and international law in resolving armed conflicts between States.

e. Review the difficulties and constraints to the efficient and effective application of international law, and the most important proposals for reducing such difficulties and constraints.

\section{Research Methodology.}

Two approaches have been adopted in this research:

a. Descriptive Approach: This approach is based on describing the phenomena and incidents in question, and then analyzing and interpreting them to draw the necessary conclusions.

b. Historical methodology, this methodology tracks events historically, and used this approach in the first section in the stages of development of international relations. 


\section{International law and international relations}

Relations at the international level now range from conflict, peace, agreement and war, on various intellectual, social, military, political and even geographic aspects, with which it becomes necessary to have a legal officer who protects the agreement and determines the dimensions of the conflict and seeks to end it by all available means, to reduce the effects The devastation of any conflict of any kind, which led to the emergence of international law, which came with principles and principles agreed upon internationally, governing relations between States.

In order to determine the peaceful and necessary means of resolving the conflict, it is necessary to know whether the dispute meets the conditions of the international dispute, and if it is ascertained that the dispute is subject to the provisions of international law, it should be known whether the dispute is political or legal and then choose the appropriate means of the dispute (Al-Fatlawe, 1995) .

In this topic, the concept of international law and international relations and the stages of their development, as well as the international conflict and the means of managing different crises, and the importance of international bodies and international law in regulating relations between different countries were discussed.

\subsection{The concept of international law and international relations and stages of development.}

5.1.1 The concept and origin of international law

International law is defined as: "The rules governing relations between independent states. Persons under this law are subject to the authority that establishes and enforces the law. International law is a law of co-ordination that only recruits cooperation among States; Sovereignty in assessing the extent of his rights" (Abdullah, 2012) a. International law in the resolution of armed conflicts is also one of the most important branches of public international law and has so far saved them by saving millions of people, because its aim is to protect people and property in the event of armed conflict. The rules of international law restrict the right of parties to a conflict to choose means and methods of warfare that could kill millions of people if attempted to use them due to the technological and scientific development associated with the production of means of warfare. $\mathrm{n}$ this sense, international law in conflict resolution can be defined as: "The set of international norms derived from international conventions and customary norms specifically aimed at solving humanitarian problems arising directly from international and non-international armed conflicts that restrict, for humanitarian reasons, the right of parties to conflict to use methods and methods(Tim, 2010). The concept of international conflict extends to contradictory claims between two or more international legal persons, which require its settlement under the rules of international law(Al-Fatlawe, 1995).

The history of armed conflict and war dates back to the origin of mankind itself. Although these conflicts and wars have sometimes known a number of customary practices, States have not established international rules and principles in the field of armed conflicts and wars to limit their effects until nearly 150 years ago. Beginning with the Geneva Conventions, which are the most prominent in the field of relations between states and international law, these conventions form the cornerstone of international law. (16) countries signed the first of these conventions in 1864, where this year came as a turning point in the process of establishing a set of legal texts. Organization for Inter-State Relations The Geneva Conventions evolved in 1906 and 1929. In 1899 and 1907, the Hague Conventions were adopted (Tashtoush, 2010), mainly aimed at regulating the conduct of war, and the Geneva Conventions were adopted. In addition to organizing armed conflicts, improving the conditions of those wounded, and protecting prisoners of war, the conventions included the issue of the protection of civilians, and a series of other international conventions covering specific areas such as conventional and chemical weapons and mines were annexed to the Geneva Conventions. , Laser weapons and cluster munitions, finally came The protection of children in armed conflict to expand the scope of international law.

5.1.2 The concept of international relations and their origin

As a result of the importance of relations between human beings and modern societies, international relations have evolved to their present form today, which in their general sense refers to the relations existing between states in times of war and peace. There are many definitions of international relations, each concerned with a particular aspect of the statement or hint, some described as aimed at solving problems between countries, and others described as programs of action in the external dimension containing the objectives and means intended for the State, the Encyclopedia British International Relations defined As "relations between the governments of independent states and used as a synonym for the meaning of international politics"(British encyclopedia, 2009), as well as: "relations established by sovereign independent states with other states to achieve certain objectives by strategic means established by those States, by which they try to protect their interests and security in The framework of the available resources and capabilities of the national force with its various elements, whether material or non-material"'( Al Muhairi, 2005).

The stages of development of international relations can be traced as follows:

a. The history of international relations dates back to the Treaty of (Westalvia) in 1648, where the countries focused on the establishment of diplomatic relations between them, in which diplomatic exchange and the 
opening of embassies in any two countries. It also continued until the period between World War I and World War II.

b. The twentieth century witnessed many developments, most notably the development of the media, and the formation of nation-states. This century was an important milestone in the history of international relations, as the world's suffering from World War I and II led to the search for means and mechanisms that contribute to the establishment of peace and security and maintain the stability of international relations. The end of World War II in 1945 led to the establishment of the United Nations, which is today the first international guarantee to regulate relations between States and reduce conflicts and disputes between them, and achieve international security and stability.

c. After the fall of the Soviet Union in 1991, the United States became the most influential country in the world. Because of new factors that did not exist before, the shape of international relations began to change. The mechanisms created by the world's nations to prevent regional and international conflicts have not helped to end them, such as the United Nations, but they have had positive efforts in many areas.

d. At present, the most prominent feature of international relations is the lack of privacy of states, and the retreat of the principle of non-interference in the internal affairs of States, which is one of the principles of the United Nations for international relations, which means that the state cannot remain isolated from the rest of the countries, where all relations, whether they are party Whether or not, the role of international law in regulating international relations has emerged even more.

\subsection{International conflict and the means of managing various crises.}

The international community has not neglected to put in place several peaceful means to resolve international conflicts and manage various crises, and to develop rules for the development of friendly relations between States and away from creating conditions that may endanger international peace and security. (1899), and until the present time all called for and expanded and organized peaceful means that maintain international peace and security. It is worth mentioning that there has been an international desire to activate the United Nations and the Security Council to maintain international peace and security, justice, tranquility, democracy, respect for human rights and combating terrorism.

International means of crisis management vary and are either diplomatic means such as good offices, negotiations, and the submission of disputes to international and regional organizations, or legal instruments such as international justice. Either restraining means such as economic pressures such as freezing or seizure of funds, or resorting to military force as a last resort (Abu Haif, 2000).

Article 33 of the Charter of the United Nations, in its second paragraph, makes it clear that the various means, in addition to the provisions of the Charter elsewhere, stipulate that the dispute should be submitted to the international body if it is difficult to resolve by one of the aforementioned means. So the following:

- Article 1 (2) states: "The development of friendly relations among nations must be promoted on the basis of respect for the principle of the equal rights of peoples and the right to self-determination."

- Paragraph (3) of Article (2): "All members of the Commission shall settle their disputes by peaceful means in a manner that does not endanger international peace, security and justice."

- Articles (33 - 38). Demands the search for peaceful means to resolve international disputes.

\subsection{International bodies and organizations and international law.}

As a result of the international conditions experienced by humanity, especially conflicts and world wars, there has been a need for the existence of bodies and organizations within which sovereign and independent States are gathered to contribute to their responsibilities towards the development of the human society, and to perform multiple functions in the service and protection of humanity such as those of collective security and international peace, Protecting migrants and refugees, contributing to education and human development, among others. The importance of international organizations and bodies and their role in law enforcement, as well as examples of those organizations and organizations currently engaged in international relations, will be illustrated as follows: 5.3.1 the importance of international bodies and organizations.

International organizations and bodies play an important role in regulating relations between different countries. They monitor these relations to preserve the rights of those countries based on international law. The reality shows the increasing importance and role of international law in controlling international relations, not to mention the evolution of the moral human values system. It has the force of law to influence the conduct of states in international relations. For example: "The United Nations has the ability to impose deterrent sanctions in all fields on states that commit aggression, violate human rights or refuse to comply with international legitimacy. States are supporting UN positions and resolutions in cutting or stopping aid or in exercising economic boycotts and others against countries that violate the rules of international law "( Tashtoush, 2010).

The maintenance of peace, security and the proper settlement of international disputes are of particular importance. They are among the primary tasks of any public international organization. It is promoted by 
international organizations and has become the scientific orbit of all its other activities(Al-Fatlawe, 1985). 5.3.2 The role of international bodies and organizations in the application of international law.

International bodies and organizations play their part in the application of international law; they have a certain degree of autonomy that separates them from the participating States or their founders, as well as their ability to operate in their own name within the limits of international law. Member States shall commit themselves to the implementation of the resolutions of those bodies and organizations based on the provisions and principles of international law.

5.3.3 Examples of international bodies and organizations at present.

As examples of today's international organizations and bodies, there are four of them, as follows:

1) Peacekeeping: A UN body whose purpose is to establish an armed force to assist Member States in protecting them from external aggression and maintaining their internal security.

2) nternational Committee of the Red Cross and Red Crescent. An international body of many bodies, all of which aim to prevent and alleviate human suffering, and to ensure respect for human beings, especially in times of armed conflict.

3) The World Health Organization (WHO) is an international organization of the United Nations specialized in the field of health.

4) WTO. A global organization specialized in the field of trade whose main mission is to ensure the smooth and free flow of trade between different countries, and to increase the volume of world trade, investment, employment and income growth throughout the world.

\section{The foundations and principles of international law in conflict resolution}

This paper deals with the principles and principles of international law through research in the sections of contemporary international law in the resolution of armed conflicts, which includes the Hague and Geneva Conventions and the Protocols to the Geneva Conventions (1977), in addition to international norms that include the repetitive and customary behavior of States during the war and military occupation. In addition to reviewing the principles of operation of contemporary international law within the principle of distinction, war necessity and proportionality, and clarifying the situations in which the provisions of international humanitarian law are applied both in international armed conflict, which occurs between independent states, non-international armed conflict or the so-called (war). Eligibility), and situations where the provisions of international humanitarian law are not applied. In addition, the parties responsible for the application of international law in the resolution of armed conflicts, represented by the contracting parties (signatories to the provisions and conventions of international law), the Protecting Power (sponsoring), the International Committee of the Red Cross, the International Fact-Finding Commission, the international courts.

6.1 Sections of international law in the resolution of armed conflicts and the principles of its work.

6.1.1 Sections of international law in conflict resolution.

International law consists of four sections, which can be explained as follows:

a. The Hague Treaties (1899-1907) The Hague Treaties are among the first international texts to regulate the laws of armed conflict and related crimes in international law, and are generally aimed at restricting the form of military operations and conduct of combatants(International law and its development, 2008). A war may break out only after a previous declaration is justified, or a warning with a declaration of war on certain conditions.

b. Geneva Conventions. These treaties, since the Convention (1864) until the time of the four Geneva Conventions in 1949, were designed to protect the victims of armed conflict from the wounded and sick and the protection of property and civilian objects (International law and its development, 2008). These conventions formed a coherent legal system, with the aim of reducing the effects of war. And agree on a balance between military necessities and humanitarian considerations. Article 2 of these Conventions stipulates: "In the event of declared war or any other armed conflict between two or more High Contracting Parties, even if one does not recognize the state of war, the Conventions shall also apply in all cases of partial or total occupation of the territory of The High Contracting Parties, even if this occupation did not meet armed resistance. "

c. Additional Protocols to the Geneva Conventions of 1977. The first protocol was to regulate the legal protection of victims of international armed conflicts, and the second protocol was to regulate the protection of victims of non-international armed conflicts. The provisions of Protocol I included the content of the (four conventions) appropriate between (The Hague Act) and (Geneva Act), and incorporated through its provisions the provisions relating to the conduct of hostilities in addition to regulating the legal status of liberation wars, which became under the first Protocol of international conflicts . Protocol II is an addendum to article 3 common to the four conventions, extending the fundamental guarantees relating to judicial rights and the prohibition of specific acts(International law and its development, 2008). 
d. International norms. It is the repeated conduct of States during war and military occupation, many of which are contained in the Hague Rules and the Geneva Conventions.

6.1.2 Principles of contemporary international law.

There is a set of principles on which international law is based, first and foremost: "the principle of balance between military necessities and humanitarian considerations" (Tim, 2010); In addition to other principles, the researcher explains the following:

a. The principle of distinction. This principle is based on the need to distinguish between the civilian population and combatants, as well as between civilian and military objectives, and observance of this principle by the parties to the conflict is indispensable to ensure the protection of civilians. It is also impermissible for combatants to appear in civilian appearance through dress, social behavior and whereabouts, as well as the destruction of objects and materials necessary for the survival and survival of civilians.

b. The principle of military necessity. The necessity of war is: "the urgent situation in which there is no possibility to choose the means used by the warring parties in their immediate military actions"( Training Manual for International Humanitarian Law, 2010).

c. Principle of proportionality. This principle strikes a balance between two opposing interests, the first being dictated by considerations of military necessity, and the second being dictated by the imperatives of humanity when there are no absolute rights or prohibitions. It is through this principle that respect for the principle of proportionality should be ensured in all military operations to prevent unnecessary civilian suffering (Training Manual for International Humanitarian Law, 2010).

6.2 cases where the provisions of international law apply.

International law is based on taking into account the devastating effects of war on persons and property, and requires parties to a conflict to abide by the laws and customs of war. According to international law, armed conflict takes two forms:

a. International armed conflict. In the case of recourse to violence between two or more States, this is called an international armed conflict. National liberation and liberation movements in international armed conflicts, in addition to the state of conflict to which international organizations are a party.

b. Non-international armed conflict. Civil war has been called internal armed conflict. Civil wars have long been outside the framework of international humanitarian law. One of the fundamental rights of the victims of internal armed conflicts until the conclusion of the Second Additional Protocol to the Geneva Conventions (1977). International humanitarian law sets out a set of principles governing the existence of internal armed conflicts, which stipulates: From conducting continuous and coordinated military operations.

6.3 Law enforcement agencies in resolving armed conflicts.

The international conditions experienced by humanity, especially world wars, have imposed the existence of organizations within which independent sovereign states are united in order to contribute to their responsibilities towards the development of the human society and perform multiple functions in the service and protection of humanity, such as collective security and international peace, and the resolution of armed conflicts, through agreements. Laws regulating this, above all international humanitarian law (Tashtoush, 2010). The responsibility for implementing these conventions rests with States parties to the IHL instruments in general and disputing parties in particular. The main actors entrusted with the application of IHL will be reviewed as follows:

a. Contracting Parties to International Law (Contracting). All Contracting States are obliged to respect, enforce and widely disseminate the Conventions. Preparations for such peacemaking shall begin in the form of practical programs and appropriate procedures. The Geneva Conventions obliged states to enact legislation and regulations to implement IHL at the national level, and to make contracting or disputing parties abide by the rules of the Geneva Conventions that left them free choice. In addition to ensuring the expertise and competence of military and civilian officials in the implementation of international humanitarian law, and supporting the armed forces with legal advisers to help commanders to carry out their full tasks and to provide opinion and advice when needed.

b. Protecting Power. In accordance with international humanitarian law, the Protecting Power is: "a neutral Contracting Party which the parties to the conflict agree to appoint to take care of the interests of one another"( International law and its development, 2008).

c. International Committee of the Red Cross. The Geneva Conventions explicitly state the role of the ICRC as it relates to the development of international humanitarian law since its inception and its follow-up. The ICRC is: "A non-governmental commission concerned with the application, respect and dissemination of awareness of the principles of international humanitarian law. It was established in 1863 and is now expanding worldwide. The legal status of the ICRC is, as a whole, an independent, impartial and impartial NGO with the mandate of States to protect and assist victims of armed conflict through the Geneva 
Conventions(International law and its development, 2008). They have a crucial role to play in respecting international humanitarian law, stopping its violations and raising awareness of its provisions among the various groups concerned.

d. International Commission of Inquiry. The work of this committee shall be determined by conducting investigations into internal conflicts if the parties to the dispute agree. The Commission's work has been formally in force since 1992(Bassiouni, 2009). In certain cases, the Commission may also open an investigation at the request of one of the parties to the conflict, provided that the other State concerned is admitted. The Committee shall submit its confidential reports to the State to which this function is entrusted.

e. International courts. The IHL instruments include the means and procedures required for liability for violations of humanitarian law(Bassiouni, 2009). The general rule of responsibility applied in international law is to violate international humanitarian law, i.e. the party violating its provisions bears the consequence, and therefore provides for reparation and compensation. International law recognizes the principle of responsibility: "No Contracting Party shall relieve itself or another Contracting Party of the responsibilities incurred by it or another Contracting Party for grave breaches". International law also provides that: "Contracting Parties undertake to take action And prosecution of war crimes, regardless of their nationality on the basis of the principle of prosecution and extradition, and what the various national authorities do in this area does not preclude international prosecution. "* Some of its applications have been the Tribunals for the former Yugoslavia and Rwanda, in particular their specific framework and formed by a decision of the Security Council to prosecute war crimes committed on the territory of the two crimes.

\section{Strategies for the settlement of disputes in international law}

International law contains many provisions for the resolution of conflicts between different countries. It also included the role of the United Nations, the Security Council and the International Committee of the Red Cross as international organizations for the resolution of conflicts. Armed within the international law, as well as the Organization of the Islamic Conference, the League of Arab States and regional organizations.

\subsection{Strategies for the resolution of armed conflict in international law.}

There are several strategies for the implementation of international law in the resolution of armed conflicts, which can be summarized as follows:

\section{a. Prevention or prevention strategies.}

These strategies are used prior to the application of the provisions of international law for the benefit of victims, and are intended to ensure that they are properly applied where appropriate, and include:

1. Respect of international law by the countries concerned. The best guarantee for the application of international law in conflict resolution is for States to respect and uphold the principle of the Covenant, since by formally agreeing to the Geneva Conventions and acceding to their Additional Protocols, they have made a commitment to ensure respect for these Conventions within their jurisdiction(Shalaldeh, 2005). Fulfilling and abiding by the Covenant affirms respect for and also respect for international law. The State is obliged to do everything in its power to ensure that the rules in question are respected by its organs and by all those under its authority.

2. Public dissemination of international law conventions. Ignorance of international law, its provisions and conventions and their failure to observe them lead to human suffering and loss of human life that can be avoided if the law which prohibits them is enforced and put into practice. Sanctions that can be carried out against perpetrators of violations of international law do not erase the tragedies and scourge resulting from such violations, and victims cannot uphold and defend their rights unless they are aware of them.

3. Training of qualified persons and appointment of legal advisers in the armed forces. The process of implementing international law in the resolution of armed conflict requires not only knowledge of the provisions of these instruments, but those who have direct responsibility in its implementation must receive special training to be able to carry out what their State has committed to, as well as to ensure the expertise and competence of officials. Military and civilian implementation of international humanitarian law It was necessary and necessary to support the armed forces with legal advisers to assist commanders in carrying out their full tasks and to provide opinion and advice when needed.

\section{b. Supervision and control strategies.}

Each country in peacetime can ascertain how the other country treats its citizens and how they apply international agreements. Between the belligerents, any direct verification of the situation is forbidden except on the battle front, and a state that indirectly knows that its adversary does not fulfill its obligations will not find the time to investigate the situation(Abu Haif, 2000). Supervision and control strategies can be adapted through:

1. The obligation of the parties to the conflict to end the violations that occur. International law imposes a general obligation on Contracting Parties to put an end to violations of international law in the event of 
armed conflict as follows:

a. General commitment. Since the parties have a permanent obligation to respect the conventions they have agreed to, they must take the necessary measures to ensure respect for the law, especially during armed conflict, and it is not excluded that individual violations can take place, no matter how efficient and effective the training is. The Contracting Parties shall end such violations within the general obligation to respect international law conventions in the resolution of armed conflicts.

b. Obligations of military commanders. The provisions of the law concern the obligations of military commanders and respect for international law in resolving disputes. To the competent authorities, in respect of members of the armed forces under their command and others acting under their supervision"(International law and its development, 2008).

2. The Protecting State. The Protecting Power shall be known as the State guaranteed by another State (known as the State of origin) under the auspices of the interests of its citizens vis-à-vis a third State (known as the State of Headquarters), and thus shall be prepared in agreement with one of the disputing States to ensure the interests of one Party to the other Party and to protect its nationals and persons. *. The Protecting Power in armed conflict has a dual function, contributing through its delegates to the direct application of international humanitarian law by undertaking relief and protection work for victims, while overseeing the fulfillment of its obligations by the parties to the conflict. Although the tasks entrusted to the Protecting Power are extensive and varied, there has been little use of the Protecting Power provided for in international law conventions (Mohamed, 2011):

- Fear that the designation of a Protecting Power would be seen as recognition of the other party (when it is not recognized).

- The unwillingness to acknowledge the existence of an armed conflict or that differences of opinion take the form of a conflict.

- Maintaining diplomatic relations between the warring parties.

- Difficulty in obtaining neutral states acceptable to both parties, capable and willing to act in this capacity.

\section{c. Repression strategies.}

Repression strategies aim to implement international law by contracting parties to enact legislation to criminalize acts and irregularities committed in armed conflict, to establish individual criminal responsibility, to bring to justice those responsible for such violations, and to establish rules of international cooperation in criminal matters that facilitate extradition. With regard to the responsibility of senior officials and leaders. The past century has witnessed profound and accelerated developments in the rules of international humanitarian law in the application of the principle of criminal accountability for serious violations of the rules of international humanitarian law, when two special international criminal tribunals were established by Security Council resolutions to try war criminals in Yugoslavia and Rwanda, and the International Criminal Court in 1998) (Tim, 2010).

\subsection{The role of international organizations in resolving armed conflicts.}

International organizations have many different mechanisms for resolving or reducing armed conflicts under international law. The United Nations, the Security Council, the International Court of Justice and the International Committee of the Red Cross are the most important organizations and bodies working to implement international law in resolving armed conflicts. The researcher reviews the role of these organizations in resolving armed conflicts in the following:

a. United nations. The United Nations is an organization of sovereign States that provides the necessary mechanisms to help find solutions to international problems or conflicts and to address the pressing concerns of humanity everywhere. Global peacekeeping is one of the main purposes of the United Nations. It has helped resolve many inter-state conflicts, prevent conflicts and put an end to hostilities. It has also undertaken complex operations, including peacemaking, peacekeeping and humanitarian assistance. The means available to the United Nations in this area range from the use of undeclared diplomatic contacts during informal interviews to the dispatch of peacekeeping forces composed of units volunteered by Member States. Since 1948, the United Nations has undertaken more than 40 peacekeeping operations, 30 of which since 1988. The number of military personnel who have served in the United Nations forces since 1948 is more than 750,000 (Tim, 2010)

b. Security Council. The Security Council is one of the most important organs of the United Nations and is responsible for the maintenance of international peace and security in accordance with Chapter VII of the Charter of the United Nations. The Security Council has legal authority over the governments of Member States, and its decisions are therefore binding on Member States. Its functions are: to maintain international peace and security in accordance with the principles and purposes of the United Nations; to investigate any dispute or situation that may lead to international dispute; The conditions for a settlement, to identify any 
threat to peace or any act of aggression, to recommend actions to be taken; to take military action against the aggressor(Dakkak, 1999); and on several occasions, the Council issued ceasefire instructions that were important in preventing the spread of hostilities.

c. International Tribunal. The International Court is: "A United Nations arm aimed at resolving disputes between States"(Bassiouni, 2009) Legal evidence of crucial or conclusive evidentiary value. The International Court of Justice has issued numerous final and binding judicial decisions to the parties to the dispute, which have contributed to the establishment of a number of legal principles, foundations or norms that have become common practice in international action and have become a fundamental reference for the adjudication of any border dispute between two or more States(Kakai, 2012).

d. International Committee of the Red Cross and Red Crescent. With regard to the prevention of armed conflict, the ICRC cannot play a role in political negotiations aimed at avoiding an impending armed conflict, but it can sometimes contribute in an effective way through preventive humanitarian diplomacy, its good offices and the innovative use of its role as a neutral intermediary. Pledge to make every effort that can contribute to the prevention or settlement of possible armed conflicts, in constant and reciprocal contact with the United Nations and within its humanitarian mission, and to participate in any appropriate measures leading to this end in agreement with the States concerned. It works as an aide and is doing its best to help the warring parties resume contact either to face the humanitarian problems caused by the conflict or to seek a political solution. The ICRC's ability to prevent armed conflict in its early stages is limited, although it can do much to create a climate of respect for individuals through its educational work and its efforts to promote human dignity(Report of the United Nations, 2010).

\subsection{The role of regional organizations in resolving armed conflicts.}

Many regional organizations contribute to the peaceful resolution of armed conflicts among their members, including the Organization of the Islamic Conference and the League of Arab States. The researcher reviews the role of these two organizations in resolving armed conflicts, as follows:

a. Organization of the Islamic Conference. The organization includes (45) Islamic countries, and is the only regional intergovernmental organization that promotes on religious grounds, namely belonging to Islam which gives it a distinct status from other regional organizations(Report of the United Nations, 2010). The most important actions of the Organization of the Islamic Conference in the resolution of disputes include:

- The Organization condemned the Iraqi aggression against Kuwait, and demanded the immediate withdrawal of Iraqi forces from Kuwaiti territory and return to pre-2/8/1990 positions, and adhering to the principles of the Charter of the Organization of the Islamic Conference, in particular the need to settle disputes between Member States by road. The organization stressed that it will follow up the implementation of the Iraqi pledge to withdraw from Kuwait after agreeing to do so unconditionally.

- On the subject of the armed conflict between Iraq and Iran, the Organization of the Islamic Conference (8/1982) asked Iraq and Iran to cease fire and withdraw immediately to the internationally recognized borders and accept the idea of forming an observer force of the members of the Organization to oversee the cease-fire and withdrawal. Resolution No. 8 / 4QA, on the conflict between Iran and Iraq, expressed its appreciation for the efforts made by the Islamic Peace Committee, and requested the Committee to continue and intensify its efforts to stop the fighting between the two countries and to reach a just and honorable settlement of the dispute between them. Call on the parties to the conflict to stop all practically The war immediately and withdraw their forces to the internationally recognized borders (Report of the United Nations, 2010).

B. League of Arab States. It is an organization that includes countries in the Middle East and Africa and its members are Arab countries. Its charter provides for coordination among member states in economic affairs, including trade relations, communications, cultural relations, nationalities, travel documents and permits, social relations, and health. The permanent headquarters of the League of Arab States is located in Cairo(Mahi, 2017), the capital of Egypt. The most important actions of the League of Arab States in resolving disputes include:

On the issue of the Moroccan-Algerian conflict (1963), the League Council issued a resolution calling on the two countries to withdraw their forces to their previous positions, with the formation of a mediation committee to take the necessary provisions to resolve the conflict by peaceful means. It was (1964), the beginning of taking measures to end the conflict.

- The League issued a resolution in 1972 to end the border crisis between North and South Yemen.

- The League of Arab States was able to end the border dispute between Kuwait and Iraq in 1961 after the intervention of Arab emergency forces. This conflict re-emerged in 1973, and the League intervened again and its efforts resulted in the establishment of a mixed committee to demarcate the borders and end the conflict(Al-Otaibi, 2016). 


\section{The future vision of the role of international law in achieving global and regional Arab security}

This paper reviews the main causes of the emergence of international armed conflicts, and the future vision of the role of international law in achieving global security by identifying the elements of achieving global security, in addition to the impact of the application of international law on Arab regional security.

\subsection{The most important reasons leading to the emergence of international armed conflicts.}

The causes of international armed conflicts are primarily political and economic factors, and the poor use of resources and environmental degradation, particularly disputes over water resources, are among the causes. Globalization plays a big role in fueling wars, as it deepens the gap between rich and poor countries, and between rich and poor within the state itself. Disparities in wealth lead to resentment and are factors that may lead to armed conflicts, as well as inequality and justice among members of one society. In the absence of the rule of law and the authority of the state, the most important reasons leading to the emergence of international armed conflicts are:

a. Border disputes. The colonization of borders by major powers and demarcation of their borders without regard to ethnic composition, especially in the Arab countries and some countries of the Middle East and Africa, led to regional conflicts on the border in an attempt by those countries after independence to modify the border, as happened between Iraq and Iran on the Shatt al-Arab As well as the border dispute between Somalia and Ethiopia on the Ogaden region, the border war between Eritrea and Ethiopia, the border dispute between Sudan and Egypt over the Halayeb triangle, and other border disputes (Mahi, 2017).

b. Weakness of the United Nations. Since its establishment, the United Nations is clearly subject to the wishes and orientations of the major Powers, in particular the Security Council and related resolutions, and its inability to achieve legal balance and equality between States. Conflicts because of their impartiality and interference in the internal affairs of States to satisfy the wishes of the major powers mainly and those who provide them with money.

c. The emergence of unipolar. After the collapse of the Soviet Union, the unipolar uniqueness of the United States emerged. Unipolarity is defined as: "a system governed by a politically, economically and militarily dominant central state with a group of states supporting it in its decisions"(Ferhad, 2004). Create an imbalance in international decision-making. The imbalance in international resolutions has led to armed conflicts between countries as a result of favoritism of one country over another by the United States, such as the dispute between India and Pakistan over the Kashmir border area. Fueling the conflict over that region.

d. Doctrinal conflicts. It is the struggle between some faiths and other religious groups, such as the crusade against Muslims in Afghanistan, Palestine and Sudan under the pretext of fighting terrorism. There are civil wars that arise between Christian groups with each other, such as the conflict between Protestants and Catholics in Europe, and conflicts between the same religious groups, such as the conflict between Sunnis and Shiites in Iraq. Attempts to obliterate Islamic identity in Bosnia and Herzegovina, and European pressure on Turkey, the old Islamic state to give up its constants and Islamic history so that it can join the European Union.

e. Economic gap. The existence of a large economic gap between the major countries and third world countries, and the economic struggle between these countries to find new economic resources such as the economic competition between America and China in Africa, led to armed conflicts between third countries as a result of competition between the major countries.

f. International ambitions. These include controlling global strategic sites such as the Straits of the Seas, Oceans and World Islands to ensure free trade and to facilitate military movements of naval fleets, as well as control of the natural wealth of oil and industrial materials and other wealth.

g. Conflict over water resources. Armed conflicts between states are expected to occur because upstream countries insist on monopolizing as much or all of their water as possible from their territory, which will cause consuming countries to lack water, which is imminent among many countries.

\subsection{The future vision of the role of international law in achieving global security.}

Public international law is concerned with the phenomenon of armed conflict and its laws. Global security is defined as: "the ability of societies and states to maintain their independent entity and their functional cohesion against the forces of change that they consider hostile"( Hussein, 2015).

Global security in international relations requires each party to make itself a guardian, that is, the use of force against any other country resists the collective force of all other countries. Global, in the following:

a. Elements of achieving global security. In order to achieve global security, there must be positive commitments from the States concerned, the most important of which are:

- Prohibition of the use of force or the threat of force in international relations, except through the United Nations, or in the case of self-defense. 
- Obligations arising from international treaties between Member States in all economic, social, military and border areas must be respected, as well as non-interference in the internal affairs of other States.

- To settle international disputes by peaceful means, through the use of international organizations that take into account the interests of Member States, and to invoke any dispute to international law and the provisions contained in the settlement of disputes.

- The need for impartiality and objectivity in the global security system and the conventions, treaties and legal provisions that are governed. Global security does not allow alliances with other countries against other countries.

- The ability of international organizations regulating international relations and international law to achieve deterrence and without prejudice to the obligations contained in the system of achieving and strengthening global security. That is, it requires that international organizations and international law enforcement have the coercive means they can resort to in the face of a State that breaches the obligations imposed by the regime. These are the so-called sanctions or sanctions.

b. The role of international law in achieving global security. International law, through its conventions and texts, has an important role in achieving global security, starting with the idea of preventing war in the future, based on a set of objectives and principles. :

1) Prohibition of the use of force. Article 2, paragraph 4, of the Charter of the United Nations states: "International relations must be based on refraining from: the threat or use of force, the use or threat of force against the political independence of any State, the use or threat of force in any way. Another does not conform to the purposes of the United Nations"(). This means that all States Members of the United Nations must refrain from the threat or use of force as a means of resolving international disputes, thereby enhancing the chances of achieving world peace and security.

2) Peaceful settlement of international disputes. The mechanism for the peaceful settlement of disputes has evolved to take a specific formula in Chapter VI of the Charter of the United Nations as an integral part of the global security system. Global security is based not only on deterring aggression, but also on a specific prevention mechanism established by international law, by requiring parties to any conflict that would endanger the maintenance of international peace and security, or seek to resolve it through negotiations, mediation, arbitration and judicial settlement. They resort to regional agencies and organizations, as confirmed by Article 33, paragraph 11 of the UN Charter (Report of the United Nations, 2010).

3) Measures to suppress aggression. The fundamental task of global security is to mobilize the forces of the United Nations Member States to suppress aggression, through collective decisions, ranging from temporary measures to decisive military ones. (When the Security Council recognizes that there is a threat to the peace, a breach of it, or an act of aggression, it has the right, with broad discretion, to issue a resolution describing the matter before it, in one of the descriptions available in the Charter, and to take the appropriate decision. Article 43 and 47 of international law stipulate: "The formation of a military force to be used for the purpose of suppressing aggression and deterring the aggressor State to maintain global security"(Hussein, 2015).

4) Therapeutic role. Within the therapeutic dimension of the United Nations system of collective security, arrangements for the imposition of international peace and security, in the event of refusal to obey a peaceful settlement or an aggression, threat or breach of peace, require an immediate response to its deterrence or repression (Hussein, 2015). International law has given the Security Council the power to assess and decide whether an act or act that constitutes a threat to or a breach of peace is authorized or authorized by the Air Force. Marine and land-based work is necessary for peace-keeping and peace International security or to restore them (International law and its development,2008).

\subsection{The application of international law and its impact on Arab regional security.}

There is no doubt that the application of international law in resolving armed conflicts positively affects Arab regional security. The researcher reviews the procedures of activating and applying international law in Arab countries, and their impact on regional security.

a. Procedures for activating and applying international law in the Arab countries. Reaffirming the obligation to respect international law and to ensure respect for it by all parties concerned, and in all circumstances, and taking into account developments related to the application of international humanitarian law at all national, regional and international levels, participants at the Ninth Meeting of Arab Governmental Experts and representatives of National Commissions In Abu Dhabi (10-12/1/2012) the adoption of a variety of specific measures to activate and apply international law in the Arab countries (Sada al-Balad newspaper, www.sadaalbalad.com), summarized as follows:

- National Committees for International Humanitarian Law. Work to continue efforts to establish national structures to advise the State on the application and dissemination of international law, and 
urge governments to continue to provide all the needs and capabilities necessary for the Arab National Committees specialized in the application of international law to play their role in line with developments in the application and dissemination of international law. .

- Legislative harmonization and ratification of relevant international conventions. By continuing to conduct national studies and researches on accession to international law conventions that have not yet acceded to them, and in accordance with the vision of each country for their interests, continue to review the national legislation of each country with a view to making recommendations on how to harmonize with international obligations Arising from international law conventions to which the State has acceded, in particular in the areas of combating war crimes, the protection of cultural property, the regulation of means and methods of combat, and the protection of the rights of missing persons and their families.

- Dissemination and training in international humanitarian law. By continuing national and regional activities for the dissemination of international law among the relevant State authorities, in particular judges, prosecutors and military judges, the diplomatic community and parliamentarians, and continuing efforts to incorporate international humanitarian law into military training programs and civic education programs, in particular undergraduate courses at law faculties Media, political science, as well as support to national committees of ministries of education to incorporate the basic concepts of international humanitarian law into basic education, as well as Red for the Red Cross in the dissemination of the provisions of international humanitarian law in the Arab region.

- International cooperation. Urging the Follow-up Committee to continue to collect data on the application of international law at the Arab regional level and the legislative and practical measures taken in this regard to facilitate the exchange of information and documents between the various Arab countries and the issuance of the Arab report on the status of the application of international humanitarian law, and to invite the League of Arab States To establish a permanent commission of international humanitarian law with responsibility for following up the application of this law at the national and regional levels.

b. The impact of international law on Arab regional security. International law has played an important role in the reduction and mitigation of some armed conflicts and the adjudication of some other conflicts in different ways in order to achieve regional peace, security and stability, including the following:

1. The dispute between Iran and the United Arab Emirates over the islands. The islands of Abu Musa, Greater Tunb, and Lesser Tunb (Arabian Islands) have been under Arab sovereignty since ancient times. Because of the importance of these geopolitical islands, they have become the target of Iranian ambitions seeking to dominate the Persian Gulf region, to fulfill its dream of reviving the glory of the Persian Empire at the expense of national security and national sovereignty of the Arab nation. They forcibly seized their property and livelihoods, and used the settlers to change the demography of the islands, to suppress Arab identity(Abdul Wahab, 2006). Since the beginning of the occupation of its islands by Iranian military forces, the UAE has sought to resolve the issue by diplomatic means, or by invoking international law and presenting the problem to international judicial bodies, where a UN resolution was issued and in accordance with international law. These islands are Arab and the UAE has the right to subordinate them, but Iran did not comply with this resolution. It is noted that the UAE's resort to international law and the United Nations to settle the dispute over the three islands, which led to the absence of war on these islands that would destabilize Regional n Gulf States and Arab countries in general.

2. The dispute over water resources between Turkey and Iraq. There is a risk of serious conflict in the Arab region caused by the water dispute in the Tigris and Euphrates rivers. The Turkish government, which owns the source of the Tigris and Euphrates, plans to build several dams in southeast Turkey for irrigation and electricity manufacturing. At least half of these dams have been completed so far. Iraq obtained from these two rivers for different uses both as a source of drinking water or in agriculture and industry. The problem of water between Turkey and Iraq is gradually becoming a major issue in the Arab national security, so that all strategic and political, economic and military issues are being dealt with; it means dealing with the Arab fate, as the water resources constitute the subject of the conflict in the region, in order to secure In order to avoid food scarcity, hunger and loss of control over economic security, and consequently loss of political independence, under the pressure of indebtedness, economic crisis and deteriorating internal security(Jubouri, 2004), international law has played an essential and effective role in identifying the Tigris and Euphrates as rivers All participating countries have the right to benefit from it fairly, which prevents war or armed conflict. This ultimately leads to security and stability in the Arab region in particular. 


\section{Conclusion}

9.1 Results

1. As a result of the negative effects of armed conflicts, international law regulates relations between States and reduces armed conflicts between them through provisions and principles that restrict the right of States parties to use methods and methods of warfare.

2. Sovereign and independent States shall establish, with other States, various relations aimed at the overall protection of their interests and security within the framework of the available resources of national power.

3. To resolve various conflicts between States, international law is based on a set of principles: the principle of balance between military necessities and humanitarian considerations, the principle of humane treatment, and the principle of distinction.

4. The provisions of international humanitarian law do not cover situations of internal tensions and disturbances as they do not fall within the scope of armed conflicts according to the standards of international law.

5. The ignorance of the rules of this law, its incompatibility with the national legislation of States and their national legislation in accordance with their international obligations, in addition to the ineffectiveness of the welfare and control system created by the Geneva Conventions, make it difficult to apply international law in resolving armed conflicts.

6. To activate the application and implementation of international law in the resolution of armed conflicts, a range of strategies are used, including prevention or prevention strategies, surveillance and control strategies, and repression strategies.

7. The most important organizations and bodies working to implement international law in resolving armed conflicts are the United Nations, the Security Council, the International Court of Justice, and the International Committee of the Red Cross and Red Crescent.

8. The ICRC contributes to the effective resolution of disputes between States through preventive humanitarian diplomacy, its good offices and its role as a neutral intermediary.

9. The United Nations has assisted in the resolution of many inter-State disputes and the prevention of conflicts and has carried out operations including peacemaking, peacekeeping and humanitarian assistance.

10. Although it is agreed that the rules and provisions of international law for the resolution of armed conflicts should be applied in most countries of the world, the rules of this law become null and void when it comes to Israel, which occupies Palestine at the heart of the Arab nation, or when it comes to the struggle of the great powers over their interests in Arab region.

\subsection{Recommendations}

1. The need to abide by the application of the principles of international law in the resolution of conflicts from all countries of the world because of its positive results on regional and global security and peace.

2. Work on the diversity of international means of crisis management, including diplomatic means such as negotiations, international investigation, good offices, and the submission of disputes to international and regional organizations, and legal means such as arbitration and international justice. Before resorting to restraining means such as economic pressure from the prohibition and freezing or seizure of funds, or resort to military force.

3. The principle of balance between military necessities and humanitarian considerations, the principle of humane treatment and the principle of distinction should be invoked in the application of international law for the resolution of armed conflicts.

4. Work to train those concerned with the rules of international law for conflict resolution, in addition to activating the system of care and control created by the Geneva Conventions.

5. The need to protect religious places to emphasize their importance to mankind in the case of armed conflict between States.

\section{References}

Abdul Wahab, Abdul. (2006). The crisis of the three Arab islands between the clarity of the UAE position and the contradiction of the Iranian position Sharjah: Dar Al Wahda Foundation.

Abdullah, Moataz. (2012). Concept of International Law, Majmaah University: College of Business Administration, Majmaah, Saudi Arabia.

Abu Haif, Ali Sadiq. (2000). Public International Law, I (3), Alexandria: Dar El Maaref Establishment.

Al-Fatlawe, Souhail. (1985). International armed conflicts, Dar Alqadeseah, Baghdad, Iraq.

Al Muhairi, Saeed Abdullah Hareb. (2005). External Relations of the Islamic State, i (3), Beirut: Dar Al-Resala Foundation.

Al-Otaibi, Ghalib bin Ghallab. (2016). League of Arab States and Arab Conflict Resolution, Riyadh: Naif Arab University for Security Sciences. 
Bassiouni,.Mahmoud. (2009). Introduction to the study of international humanitarian law and international control over the use of weapons, Cairo: Dar Arab Renaissance.

Dakkak, Mohamed Said and Hussein, Mustafa. (1999). Contemporary International Organizations, Cairo: Dar El Maaref.

Ferhad, Amer. (2004). The application of international humanitarian law, lectures on international and humanitarian law, Cairo: Dar al-Mustaqbal al-Arabi.

Hussein, Khalil. (2015). The Concept of Security in Public International Law, Lebanese University, Faculty of Law, Beirut, Lebanon.

International law and its development. (2008). International Humanitarian Law Series No. 1, Damascus: Damascus University.

Jubouri, Mohammed Tamim Mohammed. (2004). The Water Problem between Turkey and the Arab Geographical Neighborhood, Iraq, Arab Future Magazine, No. 27.

Kakai, Curran. (2012). The Role of the International Court of Justice in Settlement of Border Disputes, Master of Laws, Beirut: Beirut Arab University.

Mahi, Ahmed. (2017). Causes of conflicts in the world, online article http://waddelmahe.blogspot.com/.

Mohamed Farhad. (2011). Humanitarian Military Intervention in the Unipolar Shadow, Concept and Phenomenon Study, Unpublished PhD Thesis, Faculty of Law and Political Science, Lakhdar Batna University, Algeria.

Report of the United Nations, (What the United Nations is doing for peace), (2010)

Sada al-Balad newspaper, online, www.sadaalbalad.com,

Shalaldeh, Mohamed Fahhad. (2005) International Humanitarian Law, Jerusalem: Dar Al-Fikr Library.

Tashtoush, Hayel Abdel Mawla. (2010). Introduction to International Relations, Irbid: Yarmouk University, Department of Political Science.

The free encyclopedia website (http://en.wikipedia.org/wiki)

Tim, Qusai Mustafa. (2010). The effectiveness of international humanitarian law in international and noninternational armed conflicts, Master Thesis, An-Najah National University, Nablus.

Training Manual for International Humanitarian Law. (2010) Third Edition, Beirut: Al-Haq for Publishing and Distribution. 